建築教育認証制度の運用実態 一日・韓・米の資格への教育要件の比較一

\section{INVESTIGATION ON ACCREDITATION SYSTEMS FOR ARCHITECTURAL EDUCATION}

\section{- Comparative Study on Professional Education for Licensure in Japan, Republic of Korea, and United States of America -}

田中友章 $-* 1$ 藍谷鋼一郎 $-* 2$

キーワード

建築家資格制度, 建築教育, プログラム認証制度, 専門職学位

Keywords:

Architect license system, Architectural education, Accreditation, Professional degree
Tomoaki TANAKA $-* 1 \quad$ Koichiro AITANI $-* 2$

Accreditation systems for architectural professional education are investigated in Japan, Republic of Korea, and United States of America. In order to be registered as an architect in those three countries, requirements are defined for education, practice and examination. Critical part is ensuring the quality and outcomes of education called accreditation. Through the investigation of site visits by the three accreditation boards, common features and differences of the systems are clarified. As architectural practice expands and evolves in a global context, the portability of professional credentials becomes further more important.
1. はじめに

$1-1$. 研究の背景と目的

グローバル化の進展に伴い教育の国際化に関わる取組みが加速し ており、アジアでも国境を越えて高等教育の質を保証し、学生の双 方向交流を促進する傾向が顕著になりつつある。建築学分野でも、グ ローバルに活躍できる人材の育成が重要課題となっており、建築家 資格、教育プログラム、認証制度等からなる一連のシステムの構築 や、国際通用性の確保が重要となってきている。日本では、UIAUNESCO建築教育憲章に基づき、建築教育のプログラム認証の仕組みと して日本技術者教育認定機構（JABEE）による建築系学士修士課程認 証制度を立ち上げ、UIA-UNESCO建築教育認定委員会による機関認証 を受けて運用している。そして、認証制度の国際的通用性を高める ために、 7 つの国や地域の建築教育認証機関が本質的同等性を相互 認証するためのキャンベラ・アコードが2008年に批准され、2010年か ら発効して運用されている。

海外における建築教育プログラムについては、小澤らが1) 2) オラン ダの建築教育機関が提供するプログラムを調査・研究しており、瀬口 ${ }^{3)}$ が英国を中心とした建築教育、建築家資格、建築家職能について一連 の調查・研究を行なっているが、米国や韓国の建築教育認証制度に ついて、日本との比較も含めて扱った研究はほどんどなく、近年の 動向と実態を調查し報告することには意義がある。筆者らは、2011 年度より共同で建築家資格制度システムに関する研究を進めてお り、資格制度、教育認証制度などの比較、分類、体系化を進めてい

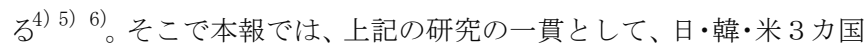
の建築家資格制度注1)について、その教育要件となる教育プログラム
認証制度の特徴や運用実態を明らかにし、各国の資格制度の歴史的 発展経緯を前提として、その特性を活かした国際通用性の確保にむ けて有用な知見を得ることを目的とする。

\section{1-2. 研究の対象と方法}

本報では、日・韓・米の建築家資格制度、およびその教育要件に 関連して、国際通用性のある教育認証を提供している教育認証機関 を、すなわち日本ではJABEE（日本技術者教育認定機構）、韓国では KAAB (韓国建築課程認定委員会注2) 、米国ではNAAB（全米建築課程認 定委員会) を研究の対象とする。そして、以下の方法と手順で調査・ 研究を行った。研究対象とした 3 機関の概要は表 1 の中段に、実地審 查の対象・実施時期等の概要は、表 1 の下段にまとめた。

(1)文献、HP等による情報収集により予備調査を行い、3 力国の建築 家資格制度および資格に関連する教育認証制度について、その概要 と近年の改定動向について調查・整理した注3)

(2)JABEEによるM大学を対象としたプログラム認証、KAABによるTN大 学校のプログラム認証、NAABによるAM大学のプログラム認証につい て、実地審査への同行調査、担当教員へのヒアリング等を行い、認 証制度の運用実態を調査した注4。

(3)調査結果の整理・分析を行った上で、考察を行なった。

\section{2. 日・韓・米の資格制度および教育要件となる認証制度}

\section{2-1。 日本の資格制度と教育認証制度}

日本の一級建築士制度は、教育要件、実務要件、試験要件からな る注5)。2008年に建築士法が改正施行されたのに伴い、一級建築士資 格に関する 3 要件が変更され現在に至っている。教育要件について は、2009年度以降に大学に入学した者は、国土交通大臣の指定する建

本稿は文献 4) および文献 5) を再構成し、修正・加筆したものである。

明治大学理工学部建築学科 教授・博士 (建築学)

(T 214-8571 神奈川県川崎市多摩区東三田 1-1-1)

*2 テキサス $A \& M$ 大学建築学部建築学科 准教授・博士 (人間環境学)

Prof., Dept of Architecture, School of Science and Technology, Meiji Univ., Dr. Arch.

2 Assoc. Prof., Dept. of Architecture, College of Architecture, Texas A\&M Univ., Ph.D. 
表 1：3 力国の資格要件、教育認証制度、実地審査等の概要

\begin{tabular}{|c|c|c|c|c|}
\hline & & 日 本 & 韓 国 & 米 国 \\
\hline \multirow{3}{*}{$\begin{array}{l}\text { 資 } \\
\text { 格 } \\
\text { 要 } \\
\text { 件 }\end{array}$} & 教育要件 & $\begin{array}{l}\text { 国土交通大臣の指定する建築に関する科目 } \\
\text { を修めて卒業（教育認証は求めず） }\end{array}$ & \begin{tabular}{|l|} 
KAABの認証を受けた 5 年制大学や大学院 \\
の卒業による専門職学位の取得
\end{tabular} & $\begin{array}{l}\text { NAABの認証を受けた専門職学位（ } 5 \text { 年制 } \\
\text { 学士、修士、博士）の取得 }\end{array}$ \\
\hline & 実務要件 & 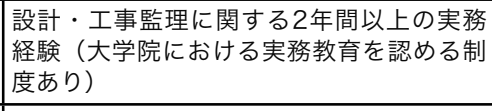 & 建築士事務所で 3 年以上の実務経験 & $\begin{array}{l}\text { 4部門で合計5600時間の実務研修プログラ } \\
\text { ム (IDP) の完了 }\end{array}$ \\
\hline & 試験要件 & $\begin{array}{l}\text { 年に } 1 \text { 回ずつ実施される一級建築士試験の } \\
\text { 学科試験と製図試験の双方に合格 }\end{array}$ & $\begin{array}{l}\text { 国土海洋部で施行する建築士資格試験への } \\
\text { 合格 }\end{array}$ & $\begin{array}{l}7 \text { 科目からなるARE4.0（建築家登録試 } \\
\text { 験）の合格 }\end{array}$ \\
\hline \multirow{5}{*}{$\begin{array}{l}\text { 教 } \\
\text { 育 } \\
\text { 認 } \\
\text { 証 } \\
\text { 制 } \\
\text { 度 }\end{array}$} & 教育認証機関 & 日本技術者教育認定機構（JABEE） & $\begin{array}{l}\text { KAAB（Korean Architecutural Accreditation } \\
\text { Board：韓国建築課程認定委員会） }\end{array}$ & $\begin{array}{l}\text { NAAB (National Architecutural Accreditation } \\
\text { Board：全米建築課程認定委員会) }\end{array}$ \\
\hline & 設立年／認証開始年 & $\begin{array}{l}\text { 1999年/2008年～建築設計·計画修士課程 } \\
\text { 認定／2012年～建築系学士修士課程認定 }\end{array}$ & \begin{tabular}{|l|} 
2005年 /2006年〜5年制学士プログラム \\
認定／2009年修士プログラム認定
\end{tabular} & $\begin{array}{l}\text { 1940年/2016年～2014年基準＋2015手 } \\
\text { 続書による受審 }\end{array}$ \\
\hline & 認証プログラム数 & 5（建築系学士修士課程認定） & $\begin{array}{l}51 \text { (学士課程50、修士課程 1） } \\
\text { (海外認定／修士課程 } 1 \text { は上記に含まない) }\end{array}$ & 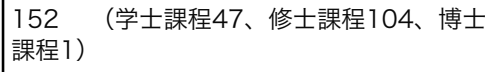 \\
\hline & キャンベラ·アコード & 正式加盟申請中（2014年～暫定加盟） & 2008年発足時から正式加盟 & 2008年発足時から正式加盟 \\
\hline & 認定基準等 & $\begin{array}{l}\text { 4つの部門（9項目）基準と分野別要件 } \\
\text { （9つの能力を具体化した学習・教育到達 } \\
\text { 目標の設定を含む） }\end{array}$ & $\begin{array}{l}\text { 37項目のSPC (学生能力目標基準)を含む } \\
\text { 認定基準（2010年基準） }\end{array}$ & $\begin{array}{l}\text { 3領域32項目のSPC (学生能力目標基準) } \\
\text { 含む認基準 (2009年基準)（2014年 } \\
\text { 基準では4領域26項目） }\end{array}$ \\
\hline \multirow{3}{*}{$\begin{array}{l}\text { 実 } \\
\text { 地 } \\
\text { 審 } \\
\text { 査 }\end{array}$} & 実地審査対象 & M大学 & TN大学校 & AM大学 \\
\hline & 実地審査日（日数） & 2015年10月18日～20日（3日間） & 2012年12月2日～5日（4日間） & 2014年2月2日～5日（4日間） \\
\hline & 審査チーム構成 & $\begin{array}{l}\text { 審査員5名＋オブザーバー2名（審査員は大 } \\
\text { 学教員3名+実務者 } 2 \text { 名、オブザーバーに大 } \\
\text { 学院生を含む） }\end{array}$ & \begin{tabular}{|l|} 
審査員5名+オブザーバー2名（審査員は大 \\
学教員3名+実務者 2 名、学生は含まれな）
\end{tabular} & $\begin{array}{l}\text { 審査員4名＋オブザーバー } 1 \text { 名（審査員は大 } \\
\text { 学教員＋実務者＋学生＋資格認証機関係者地域の実務者を含む） } \\
\text { 者、オブザーバーに }\end{array}$ \\
\hline
\end{tabular}

築に関する科目を修めて卒業することで教育要件に準拠するかたち に変更された。これらの科目については、各高等教育機関が所定の 基準への準拠を所管機関に確認申請を行うことで確認する仕組みと している。よって、現行の建築士法では、教育要件として第 3 者機 関による教育認証を得た学位であることを求めている訳ではない。

実務要件については、設計・工事監理に関する 2 年間以上の実務 経験を求めている。従前は修士課程の 2 年間により実務要件を満た すことが可能であったが、法改正後 2009 年度以降に大学院に入学し た者は、国土交通大臣が定める大学院における実務経験に関わる単 位を所定の単位数以上取得すれば建築実務 1 年または建築実務 2 年 の経験が認められるかたちに変更された。

試験要件については、年に 1 回ずつ実施される一級建築士試験の 学科試験と製図試験の双方に合格することを求めており、2009年度 の改訂で学科試験の科目数、試験時間、出題数等が変更され、製図試 験も試験時間、出題内容等が変更された。これと合わせて、製図試験 が不合格の場合の学科試験の免除回数も 2 回へと変更されている。

教育に関わる第 3 者機関による教育プログラム認証 (Accreditation) については、日本技術者教育認定機構（JABEE）が工農理系の教育ブ ログラムの認定および産業技術系専門職大学院の認証を行なってい る。建築学分野では、2003年からワシントン協定に基づくエンジニ アリング学士ブログラム認定が行なわれているが、これに加えて、 UNESCO-UIA建築教育憲章に基づく教育認定システムとして大学院修 士課程 (2年間)を対象とする認定が付加され開始されている。2008年 にUNESCO-UIA建築教育認定委員会の審查団が実地審查を行ない、 JABEEが 5 年間の条件付き機関認証を受けたことにより、UESCO-UIA が直接認定する教育プログラムとの同等性が保証されることとなっ た。その後、所定の改善事項への対応を整えて、UNESCO-UIA教育憲 章に準拠した分野別要件を新たな個別基準とする2012年基準によっ て、修士・学士 6 年一貫の教育プログラム認定「建築系学士修士課
程」を新たな認定種別として開設し、国際通用性のある教育認証の 仕組みを整えている。現行のJABEE2012年基準では、学士課程プログ ラムについて「一級建築士」の受験資格要件を満たす科目を開設する ことを求めているのに加えて、修士課程プログラムにおいて「一級建 築士」受験に必要な実務経験 1 年に相当する単位が取得できる科目を 開設することを求めている。これら双方の規定により、教育要件と して資格との一定の関連性を持つものとなっているが、一級建築士 の教育要件として当該プログラム認証は必須ではないため、双方の つながりは限定的であると考えられる。キャンベラ・アコードにつ いては、発足当時は国内に対応できる認証機関や教育認証の仕組みが 存在しなかったために非加盟であった。その後、オブザーバーとし ての参加を継続してきたが、JABEE建築系学士修士課程認定が開始さ れ一定数の認証実績を得たのを受けて、現在正式加盟へ向けた手続 きが進められている。2014年には暫定加盟が認められ、2015年に国 内のJABEE審査に合わせて実地審査が実施された。

JABEEではプログラム認証の基準として、2012年建築系学士修士課 程認定基準においては、4つの部門（9 項目）基準と分野別要件を定 め、その中で教育プログラムに 9 つの能力を具体化したかたちで学 習・教育到達目標を設定することを求め、分野別要件としてUNESCOUIA建築教育憲章が求める能力への考慮を規定している。教育機関 (教育プログラム) は、水準を含めて設定した学習・教育到達目標を 設定した上で、学生が達成できるように教育課程（カリキュラム）を 作成し、その実施により目標を達成した成果を生み出しているか を、自己点検書と実地審査によるピアレビューによって確認し、認証 を行う仕組みとしている。まず、学習・教育到達目標を公開し、教育 成果等を記録するなどして、所定の条件を満たして正式な申請を行な ったのち、自己評価報告書を作成・提出し、3 日間の実地審査が行わ れる。結果が適合の場合は 6 年間の認証が得られるが、中間審查対象 となり 3 年の認証となる場合もある。 


\section{2-2．韓国の資格制度と教育認証制度}

韓国の建築家制度は、教育要件、実務要件、試験要件からなるが、 2011年に建築家法が改正され、予備試験が廃止されて資格試験の一 元化が行われた。新システムでは、一定の移行期間を経て注6)、KAAB の認証を受けた 5 年制大学や大学院を卒業し専門職学位を取得し、 建築士事務所で 3 年以上の実務経験を経た者のみが、資格試験を受 験できるようになる。また、建築士資格登録や 3 年毎の登録更新の 仕組みも新たに導入された。

資格の教育要件となる教育プログラム認証（Accreditation）は、 大韓建築学会、大韓建築士協会、韓国建築家協会の相互協力により 設立されたKAABにより実施されている。新制度導入に伴い 5 年制の 学士プログラムが創設され、2006年に 3 つの専門職学位プログラム の初認定を行なった後、現在は51のプログラムを認定している。認 定プログラムのうち 50 は 5 年制学士プログラムであるが、修士プロ グラムによる認定も 1 ある。また、KAABはキャンベラ・アコードにも 発足時から正式加盟している。2016年の認証を皮切りに国外のプロ グラムの正式なプログラム認証も開始している。

KAABではプログラム認証の基準として、UNESCO-UIA建築教育憲章が求 める教育目標等に基づいて、37項目のSPC (Student Performance Criteria : 学生能力目標基準) を含む認定基準を設けている。教育機 関は、SPCを充足する教育プログラムを設定し、適確な運用により成果 を生み出しているかを、自己評価報告書と実地調査によりピアレビュ 一で確認し認証を行う仕組みとしている。まず、予備審査により最小限 の要件一の準拠の判定を受けて認証候補資格を得たのち、教育成果等 を記録して自己評価報告書を作成し、正式な認証申請を行なって 4 日 間の実態調查が行われる。結果が適合の場合は 5 年間の認証が得られ るが、 2 年ないしは 3 年の条件付認証となる場合もある。

\section{2-3. 米国の資格制度と教育認証制度}

米国の建築家制度は、教育要件、実務要件、試験要件からなる。 現行の制度では、NAABの認証を受けた専門職学位を取得した上で、4 部門で合計5600時間の実務研修プログラム（IDP）を完了し、7 科目 からなるARE4.0に合格することにより、州ごとに登録される建築家 資格を得ることができる。なお、3 要件とも現在大幅な改訂が進行 中で、教育要件は、NAB認証が従来の2009年認定基準から2014年認 定基準へと改訂が行われ、新基準による認定が2016年1月1日の受審 から適用されている。実務要件は、IDPの修了要件を 3,740 時間に短 縮した上で、 4 部門を6部門へ再編する改訂が行なわれ、2016年6月 29 日以降名称がAXPに変更されて実施される。試験要件は、現行の7 科目のARE4.0から6科目ARE5.0のへ改訂の準備が進んでおり、2016年 後半からARE5.0の導入が予定されている。なお、今回の改訂に合わ せて実務要件の部門と試験要件の科目の共通化が行なわれた。

教育要件となる教育プログラム認証 (Accreditation) は、全米建築 高等教育機関協会 (ACSA)、アメリカ建築家協会 (AIA)、全米建築家 登録委員会連合協議会 (NCARB) の相互協力により設立され、現在は全 米建築学生協会 (AIAS) を加えた4機関により組織されるNAABにより 実施されている。2015年6月末の時点で、米国および属領内の122の教 育機関において152の専門職学位プログラムを認証しており、内訳は 47 が学士課程、104が修士課程、1が博士課程である。かつては 5 年制 の学士課程が大きな割合で存在したが、近年は漸減傾向であり、これ を置き換えるかたちで修士課程による認定が増加してきている。また、
NAABはキャンベラ・アコードにも発足時から正式加盟している。

NAABではプログラム認証の基準として、2009年基準においては32 項目のSPC 注7)を含む認定基準を設けている。教育機関は、SPCを充足 する教育プログラムを作成し、その実施により基準に準拠する成果 を生み出しているかを、自己評価報告書と実地審査によるピアレビ ユーによって確認し、認証を行う仕組みとしている。まず、予備審 查により最小限の要件への準拠の判定を受けて認証候補資格を得た のち、教育成果等を記録して自己評価報告書を作成し、正式な認証 申請を行なって 4 日間の実地審查が行われる。結果が適合の場合は 8 年間の認証が得られるが、 3 年の条件付認証となる場合もある

\section{3 力国の認証制度の運用実態}

\section{3-1. JABEEIよるM大学の実地審査}

運用実態の調査対象としたM大学は、東京都千代田区などに立地す る1881年に創立された私立大学である。1949年に建築学科が開設さ れて建築教育が開始され、1959年に博士前期課程（修士課程）、1961 年に博士後期課程が設置されている。1965年には神奈川県川崎市多摩 区のキャンパスに移転し、1989年に工学部が理工学部に改組されてい るが、この間建築学科は大きな組織改編なく建築教育を提供してき た。そして、2013年には英語で 2 年間の修士課程の教育を行なうプ ログラムを中野区の新キャンパスに開設した。今回は、従来からあ る建築学科と新設の英語修士コースの接合による建築系学士修士課 程の新規審査のための実地審査であった。

JABEEによる実地審查は、2015年10月18日〜20日の3日間で実施され た。表 2 の左段に現地実態調査のスケジュールをまとめた。審査チー ムは、5名の審査員と2名のオブザーバーから構成されている。内訳は 審査長も含め大学教員が 3 名、実務者が 2 名であった。UNESCO-UIA建 築教育認定に関わる取り決めに基づいて、審查長は設計・計画系の実 務者ないしは教育者が務めているほか、議決権のないオブザーバーと して大学院生が審査チームに含まれている。

成果資料・展示スペースには、M大学の教育カリキュラムに基づい て、学部・大学院の 6 年間のカリキュラムの設計科目を中心とした 成果資料に展示され、講義科目等の資料のファイルはカリキュラム 体系に基づいて整理され机上にまとめられた（図 1 左段参照）。学 習・教育到達目標は項目別にカラーコーディングされて、各科目へ の配当状況がマトリックスやファイルのラベルで表示された。ま た、設計科目については、該当する目標を学年別の段階的到達目標 や教育方法等に体系的に詳細化したチャートを示し、展示を同じ関 係で構成することで、照応関係が容易に確認できるように準備され た。なお、審査チームの作業スペースや面談用の会議室は別途設けら れた。審査員は、面談・訪問等と平行して成果資料の検討と確認を行 い順次報告書の準備を進めていった。

3 日間の実地審查期間中には、教員との面談に加えて卒業生、在 校生、学部長、大学事務職員・事務長など異なるレベルの関係者と の面談が含まれていた。加えて、製図室、教室などの建築学科の施 設を中心に、図書館・実験室など大学施設の見学も含まれていた。 これらにより JABEEの認定基準に基づいて、多面的に準拠を確認する 仕組みとしている。最終日には、受審プログラム関係者に実地審査 の成果概要を総括文として口頭で報告する面談が行なわれた。な お、認証結果は、審查チームがまとめたプログラム点検書と審査報 告書をもとにJABEEが決定し、2016年3月までに受審校へ通知された。 
表 2 : 実地審査のスケジュール

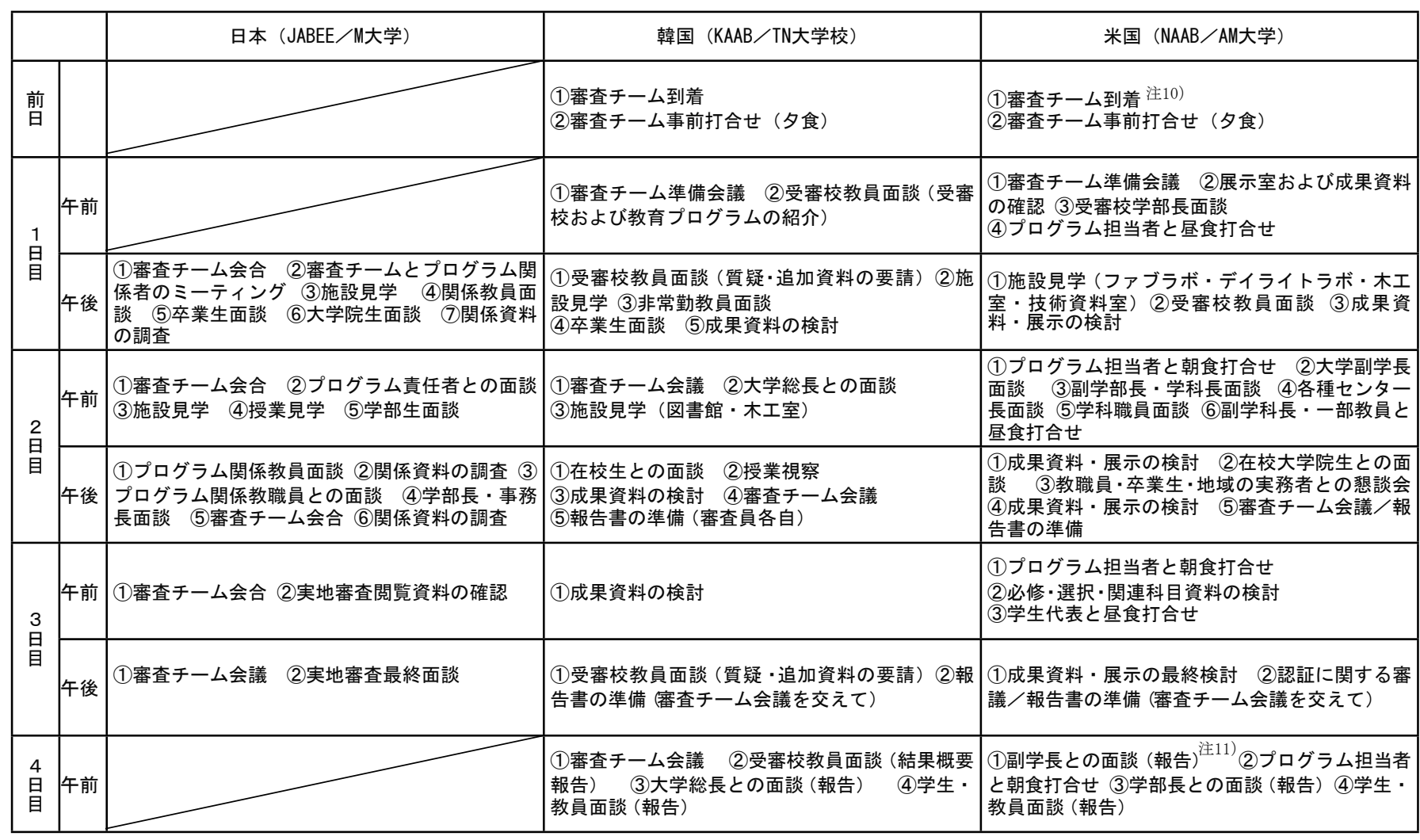

\section{3-2. KAABによる $T N$ 大学校の実地審査}

運用実態の調査対象としたTN大学校は、韓国の中部大田広域市に 立地する1952年に創立された国立大学である。建築学科は創立時か らある伝統的な学科だが、2002年に建築工学科と 5 年制プログラムを 持つ建築学科に分割された。5年制学士プログラムは既にKAABの認証 を取得しており、今回が認証更新のための実態調查であった。

KAABによる現地実態調査は、2012年12月2日〜 2 日の 4 日間で実施 された。表 2 の中段に実地審査のスケジュールをまとめた。審査チ 一ムは、5名の審査員と 2 名のオブザーバーから構成されている。内 訳は主査も含め大学教員が 3 名、実務者が 2 名であった注9)。オブザー バーには認証候補資格を得て近未来にKAABによる認証を受審する大 学からの教員が含まれている。

一日目午前の審査チーム準備会議において、主査から進行や留意 事項の説明があり、審査員の業務分担が提案された。10項目の認定 基準について、基準1 9は2名ずつ担当し、基準10のSPC部分は 37 項 目を5つのグループに分けて 3 名ずつで担当し、自己評価報告書およ び成果展示の内容の審査を行った。2名のオブザーバ一は最終評価 には参加しないが、4日間の業務を分担し、審查業務を補佐した。審 査チームの作業スペースも兼祃る成果資料の展示スペースには、TN 大学校の教育カリキュラムに基づいて、設計科目を中心とした 1 年 から 5 年の成果資料が順番に展示された (図 1 中段参照)。37項目の SPCは、各科目ごとの配当状況がマトリックスで表示され、加えて、 各成果物に番号がタグ表示されて、容易に対応が確認できるように 準備されていた。審査員は、面談・訪問等の間に担当分の成果資料 の検討と確認を行い、順次報告書の準備を進めることとなった。

4 日間の実態調査期間中には、専任教員との面談に加えて非常勤教 員、卒業生、在校生、大学幹部など異なるレベルの関係者との面談 が含まれていた。加えて、製図室、教室などの建築学科の施設を中
心に、図書館、工房など大学施設の見学も含まれていた。これらに よりKAABの認定基準について、多面的に準拠を確認する仕組みとし ている。最終日には、審査チームの会議で成果を確認した上で、各 レベルの関係者に実態調査結果概要を口頭で報告した。なお、認証 結果は、審査チームがまとめた推奨結果書と実態調査団報告書をも とに、KAABの認証委員会と理事会が決定し、2013年2月頃までに受審 校一通知された。

\section{3-3. NAABによるAM大学の実地審査}

運用実態の調查対象としたAM大学は、アメリカ合衆国テキサス州 カレッジステーション市に立地する1876年に創立された州立大学で ある。1905年に建築工学教育が開始され、1941年に5年制の建築工学 過程へと正規に移行。1948年に専門職学位として初めて認証され る。その後、幾度の組織改変を経て1969年に建築学科、環境設計学 科、建設工学科、景観設計学科、及び都市・地域計画学科から成る 建築環境設計学部が設立された。この時期から教育課程が $4+2$ に再構 成され現在に至る。2014年は、2008年に行われたNAABによる認証の 更新期にあたり、今回はその継続認証のための実地審査であった。

NAABによる実地審査は、2014年2月2日～5日の 4 日間で実施され た。表 2 の右段に実地審査のスケジュールをまとめた。審査チーム は、4名の審査員と1名のオブザーバーから構成されていた。内訳は 主査となる大学教員 (ACSA) および実務者 (AIA)、学生 (AIAS)、資格 認証機関関係者 (NCARB) 各 1 名であった。議決権のないオブザーバ 一は、AM大学の推薦により地域の実務者が務めている。

審査チームの作業スペースも兼㸚る成果資料・展示スペースに は、AM大学の教育カリキュラムに基づいて、大学院の設計科目を中 心とした成果資料 ${ }^{\text {注 } 12)}$ が順番に展示され、講義科目等の資料はファイ ルがナンバリングに沿ってラックにまとめられた (図 1 右段参照)。 SPCは、各セクションごとにカラーコーディングされて各科目への配 


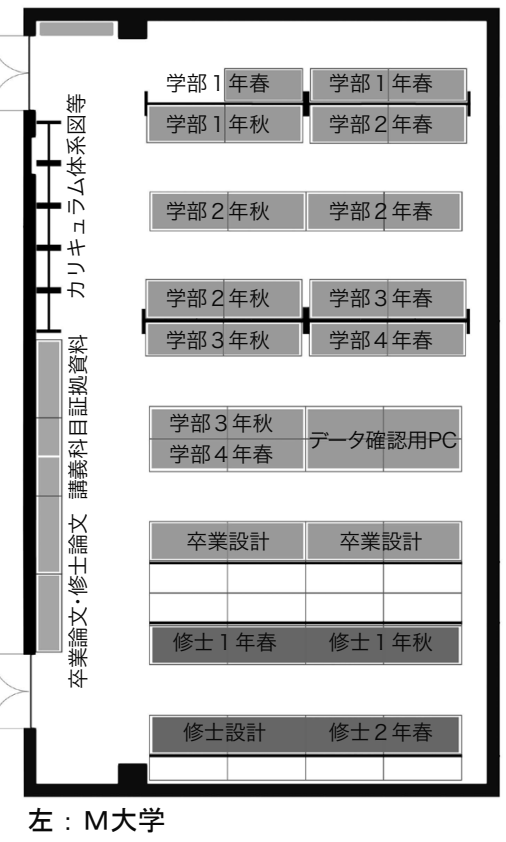

図 1 : 成果資料・展示スペースのレイアウト主 13

当状況がマトリックスで表示され、照応関係が容易に確認できるよ うに準備された。審査員は、面談・訪問等と平行して成果資料の検 討と確認を行い、順次報告書の準備を進めていった。

4 日間の実地審査期間中には、教員との面談に加えて卒業生、在校 生、大学幹部、学部・学科の役職者、大学職員、地域の実務者など異 なるレベルの関係者との面談が含まれていた。加えて、製図室、教室 などの建築学科の施設を中心に、工房、ラボ、技術資料室など大学施 設の見学も含まれていた。これらにより $\mathrm{NABB} の$ 認定基準について、多 面的に準拠を確認する仕組みとしている。最終日には、各レベルの関 係者に実態調查結果概要を口頭で報告する面談が行なわれた。なお、 認証結果は、審査チームがまとめた結果書と実態調查団報告書をもと にNAABが決定し、2014年4月頃までに受審校へ通知された。

\section{4. 日・韓・米の認証制度の比較・考察}

本報では、日・韓・米の建築家資格制度システムの概要、及び、 その教育要件等となる建築教育プログラム認証制度の概要と運用実 態について調査・研究し、報告を行なった。その中では特に、日本は JABEEによるM大学を、韓国はKAABによるTN大学校を、米国はNAABによ るAM大学を、それぞれ対象として選定して、その実地審査の同行調査 やヒアリング調查などを実施し、その運用実態を明らかにすることが できた。以下に、その比較・考察により得られた知見をまとめるとと もに、課題と可能性を展望した。

(1)日・韓・米の建築家資格制度に共通する点として、資格要件が教 育要件、実務要件、試験要件の 3 つから構成されている点があげら れる。教育要件については、韓・米の制度が教育プログラム認証を 受けた学位の取得を必須の教育要件としているのに対して、日本で は大臣の指定する建築に関する科目を修めて卒業することにより教 育要件が準拠される。その準拠は教育機関からの確認申請で担保す る仕組みとしており、第 3 者機関による教育プログラム認証を求め ている訳ではない。また、教育プログラム認証については、JABEEが 国際通用性のある教育プログラム認証の仕組みを整えているが、資 格要件とのつながりは限定的なレベルに留まっている。
(2)JABEEの建築系学士修士課程の認証については、2016年3月末現在

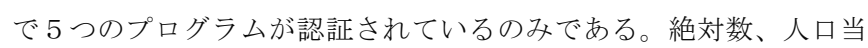
たりの数の双方の指標で比べた場合、韓・米と比べて一級建築士資 格の教育要件を提供する大学課程数は相当多いが注14)、国際通用性の あるJABEE認証を受けているプログラム数は極めて少ないのが特徴と なっている。また、日本では学位名称が教育プログラム認証の有無 とは関係なく設定される仕組みであるため、韓・米では教育プログラ ム認証を受けた学位の名称として用いられる「B. Arch (建築学士)」 「M. Arch（建築学修士）」が、日本では教育プログラム認証とは関係な く授与される可能性があり、キャンベラ・アコードが揭げる相互の本 質的同等性の確認という観点からは懸念がある。

(3)KAABの教育プログラム認証の仕組みは、NAABの仕組みを下敷きに 韓国の状況に即して移植したものであるとの説明がヒアリング時に もあったが、双方は認証制度の内容および運用について極めて類似 していることがわかった。双方とも認定基準に定めるSPCの達成を、 体系化されたカリキュラムによる成果について、ピアレビューで自己 評価報告書と実地調查により確認する仕組みはほぼ同じである。相違 点としては、KAABでは実地審査の審査チームに学生が含まれない 点、NAABでは受審校推薦のオブザーバーとして地域の実務者が含ま れる点などがあげられる。なお、KAABとNAABでは、成果におけるSPC の達成を直接的な相応関係として確認する仕組みとなっているが、 JABEEでは、認定基準に規定する能力を具体化して受審校が独自の学 習・教育到達目標を設定することを求め、成果における学習・教育到 達目標の達成を確認する仕組みとしている。また、KAABとNAABでは 実地審査は4日間であるが、JABEEの実地審査は3 日間である。

(4)受審プログラム全てで共通して、成果物の展示が行なわれていた が、図 1 の同一スケールでの比較にみられるように、TN大学校の成 果資料の展示は非常に大規模で、SPCのラベリングなども含めて徹底 していた。これは、充実した成果資料の展示となっている一方で、 準備期間も含め受審プログラム側の負担も大きく、効率性を考慮し て改善の余地があると考えられる。この点、AM大学では学生作品保 
存のデジタル化や独自のラックを活用した展示などにより小規模の 成果資料・展示スペースで目的を達成しており、学べる点もあると 考えられる。JABEEでは認定基準やその解説では成果物の展示を求め ておらず、HPへの関連情報掲載や講習会での情報提供等に留まって おり、この点は公平性ある受審条件の安定化のために改善が求めら れる。NAABでは審査ルームともなる成果資料・展示スペースの作成方 法などについて、受審校の展示の写真を含む資料やビデオなどを公 開しているほか、ACSAの管理·運営担当教員会議注15)で各種講習も提 供しており、これらにも参考になる点が多いと考えられる。

(5)KAABによる51の認証プログラムでは修士課程は1のみで圧倒的に学 士課程が多いが、NAABによる152の認証プログラムでは修士課程が学 士課程の倍以上ある。また、2008年と2015年を比較すると、学士課 程は56から47へ 9 プログラム減少し、修士課程は94から104へ10プロ グラム増加している。JABEEではUNESCO-UIA建築教育憲章に基づく教 育認定システムは学士修士課程の6年制プログラムの認証のみとなる が、大学課程としては別立である学士課程と修士課程をバーチャル に一体化するため、大学院入試がプログラム編入として扱われるな どの運用上の特殊点がある。これらに関しては、米国で漸増傾向に ある修士課程の認証プログラムにおける学士課程と修士課程との接 合方法などについて、参考にできる点もあると考えられる。

(6)KAAB と NAABは従来から本質的同等性認証を国外のプログラムに提 供してきたが、KAABは2016年1月のインドネシアでの認証を皮切りに 国外プログラムを対象とした認証を正式に開始している。NAABも 2014年基準から国外のプログラムを対象とした認証を提供できるよ う仕組みを改訂している。域内で業務独占する性質から、従来は場 所拘束性の高かった資格制度について、教育要件となる認証制度が 域外へと展開寸る傾向を見せているのは興味深い動向である。ま た、キャンベラ・アコードについても、JABEEとSACAP（南アフリカ）が 暫定加盟を終えて正式加盟を目指しているほか、2015年にはHKIA（香 港）とFMID (スペイン)の暫定加盟が認められ、IEET-AAC (台湾) が暫 定加盟の手続きをはじめるなど拡大の様相を呈しており、教育プログ ラム認証制度の国際通用性の重要度が高まっていることがわかる。

欧州ではボローニャ宣言以降、高等教育の学位資格と質保証の構造 変革が起こったが、アジア圈でも建築教育の国際化への変革の潮流は 確かなものとなりつつある。日本では、JABEE建築系学士修士課程は まだ発展途上にあるが、資格制度の信任に関わる国際通用性はさらに 重要度を増しており、今後の発展のためにもさらに研究を継続し、 実践的かつ有益な知見を得ることが重要である。

謝辞 本研究は、平成 24 年度 26 年度 (公財) 建築技術教育普及センタ 一の調查・研究助成の助成を受けて行なわれた。

\section{注}

注 1 ) Architectの訳語として「建築士」と「建築家」の双方が使われる場合 があるが、本報では「一級建築士」など固有名詞に「建築士」が使わ れている場合を除き「建築家」を用いている。

注 2 ) Korea Architectural Accreditating Boardは「韓国建築教育認証院」 と訳される場合があるが、本報では「韓国建築課程認定委員会」とした。

注 3 ） 3 力国の資格制度と教育認定制度については、以下のHPおよび文献7）、 8)を参照した。

http://www. jabee. org

http://eng. kaab. or. kr http://www. naab. org/home

注 4 ）教育プログラム認証に関する審査については、審査員及びプログラム 関倸者に一定の守秘義務が課されているため、本報ではそれらの条件
に抵触しない範囲で、同行調查およびヒアリング調查等で得た知見を 報告している。

注 5 ）日本における建築士制度には、一級建築士、二級建築士、木造建築士 があり、一級建築士の 3 要件についても大学以外の学歴とより長い実 務経験年数を組み合わせた受験要件も設定されているが、 3 力国の比 較を行なうため、本報では大学の教育要件と最短の 2 年の実務経験年 数となる教育要件の組み合わせに限定して記載している。

注 6 ）建築家法予備試験は2019年まで、旧システムによる資格試験は2026年 まで平行して運営され、一定の移行期間中は受験機会が提供される。

注 7) SPC (Student Performance Criteria : 学生能力目標基淮) は、教育プロ グラムを修了する学生が最低限到達すべき目標を設定している。2009 年基準のSPCは、A 批判的思考之表現 (A1 A11)、B 統合的建築実務・ 専門的技能と知識（B1〜B12）、Cリーダーシップと実践（C1〜C9）の 32項目である。

注 8$)$ 従来は 6 年間の認証 $/ 2$ 年の条件付認証だったが、改善のためのカリ キュラム改変のタイミングに対して性急などの理由で改訂された。

注 9 ) 審査員は、利害の衝突が無いよう出身地なども考慮して選出され、実 務者は大韓建築士協会 (KIRA) と韓国建築家協会 (KIA) からの推薦者各 1名となっている。

注10) 本実地審査では、審査長が審査開始の 2 日前に到着して、前日に資料・ 展示の確認等を行なったが、ここでは通常の日程に即して記述した。

注11）日程上の理由で、プログラム担当者と朝食打合せに先立って、副学長一 の報告面談を実施したが、通常は打ち合せ後に各種報告が実施される。

注12）前回実地審査では、 $4+2 の$ 合計6年の成果資料に対する審査が行なわれた が、NAABの認定基準の運用変更により大学院入学時の同等性確認が厳格 化されたため、大学院のカリキュラムのみでのSPC準拠を説明するかた ちで受審する大学が増加している。4+2システムは、 5 年生学士プログラ ムより 1 年長いので、より自由度が高く複線的なキャリア形成に対応し たプログラムが可能となるように思えるが、2年間のみでSPCに準拠する ためには、従前より自由度が限定されてしまうものと考えられる。

注13）各校に対する実地審査への同行調査や担当教員へのヒアリング等を行 なった際に提供された資料等に基づいて作図した。なお、M大学、TN大学 校、TM大学とも実地審查後に成績資料を撤去した上で、作品等の成果 物を公開展示しており、受審校の自発的な公開内容に基づいて、注 4) の守秘義務に抵触しない情報として提示している。本図は、同スケール となるよう作成したが、作図上の制約による誤差を含むものである。

注14）正確な統計数字が公開されていないが、一級建築士の教育要件 (実務経 験年数 2 年が必要とされる学歴) を提供する教育プログラムは約 300 程度 存在する。

注15）文献6）に詳述されているとおり、年 1 回11月頃にACSAが実施する管理. 運営担当教員会議 (Administrators Conference) では、NAABのプログラ 厶認証制度について、各種の情報提供や意見交換が行なわれている。

\section{参考文献}

1) 小澤丈夫 ; デルフト工科大学建築学部修士課程における建築教育プログ ラム, 日本建築学会北海道支部研究報告集 (86), 2013. 6., pp331-334

2) 小澤丈夫, 尾辻自然, 後藤なつみ;アムステルダム建築アカデミーにおける 建築教育プログラム, 日本建築学会北海道支部研究報告集 (85)，2012. 6.， pp335-338

3）瀬口哲夫; 英国を中心とした建築教育、建築家資格、建築家職能、公共 発注制度の国際比較に関する一連の調査研究, 日本建築学会賞 (業績), 2001. 8, 建築雑誌 $116(1475), p 95$

4 ）田中友章、藍谷鋼一郎; 韓国の建築教育プログラム認証制度の運用実態, 日本建築学会大会 (北海道) 学術講演梗概集，2013.9, E pp23-24

5 ）田中友章、藍谷鋼一郎; 米国の建築教育プログラム認証制度の運用実態, 日本建築学会大会 (近畿) 学術講演梗概集, 2014.9, E pp49-50

6 ）田中友章、藍谷鋼一郎; 米国の建築家資格制度にみられる近年の資格要件 の動向日本建築学会大会 (関東) 学術講演梗概集, 2015. 9, E pp39-40

7 ）建築士制度等に関する資格・教育の国際比較検証業務報告書，（財）建築 技術教育普及センター, 2012.3

8 ）建築士制度等に関する資格・教育の国際比較検証業務（平成26年度）報告 書，（公財）建築技術教育普及センター，2015. 3

[2016 年 6 月 1 日原稿受理 2016 年 6 月 18 日採用決定］ 